https://doi.org/10.7592/Sator.2017.18.03

42

\title{
Social Ties of Bulgarians and Rudari in the Mediterranean Countries
}

\author{
Magdalena Slavkova
}

\begin{abstract}
Balkan Ethnology Department, Institute of Ethnology and Folklore Studies with Ethnographic Museum, Bulgarian Academy of Sciences magdalenaslavkova@yahoo.com
\end{abstract}

\begin{abstract}
The purpose of this article is to explore, from an ethnological perspective, the transformed traditions of social relations of Bulgarian and Romanian-speaking Gypsy workers (Rudari) in Greece and Spain, focusing on how they cope with the challenges of living and working in different socio-economic and cultural settings. Some of those Bulgarians and Rudari are temporary migrants, sooner or later they return to Bulgaria; others turn from temporary labour migrants into emigrants. They settle permanently in the host country and adjust to the "Greek and Spanish way of life". Both groups have developed similar migration strategies in Greece and Spain but their patterns of social adaptation and the way they create social ties have ethnic specifics. The social circles formed on the base of these ties can include people from Bulgaria as well as immigrants and locals and in many cases accumulate positive integration effects.
\end{abstract}

Key words: labour migration, mobility, Bulgarians, Rudari, Greece, Spain, social ties

\section{Introduction}

Through exploration of ethnographic data this paper aims to look at social ties forged by Bulgarian citizens of different ethnic origins and generated by the transnational movement. Specifically, it focuses on two groups of labour migrants - the Bulgarians and a group of Bulgarian Gypsies, the Rudari - and their particular styles of migrant living. The article also discusses the specific ways in which the relationships between the members of the Bulgarian citizens' communities within the Spanish and Greek society have been shaped differently.

All ethnographic data used in this article and analyses related to them were made in March 2014. Some of the data, such as the number of Bulgarian civil society organisations and Bulgarian Sunday schools in Spain or Greece; the names of some associations and others, have already changed. 


\section{Itineraries of Bulgarian and Rudari Labour Mobility}

The post-socialist era was not the first time Bulgarian citizens had moved away from their homelands to work abroad, some of the ethnic minorities had also been mobile earlier. The examination of the migration process shows that contemporary labour migration is an economic strategy, this has already been verified. Labour mobility appears to have been an important part of life for the Bulgarians and Rudari throughout the ages; it has taken various forms during the historical periods and in different specific modes (gurbet, seminomadic mobility, and economic travelling during socialist times).

\section{Gurbet, Nomadism and Travelling Abroad during Socialism}

The current migratory movements resemble a traditional pattern in the Balkan area, the so-called gurbet, through which male workers migrate abroad for short periods of time in order to provide some extra income for their households while their families stay behind. Until 1878, when Bulgaria was liberated from the Ottoman rule, workers on gurbet migrated to other regions under the control of the Ottoman Empire (Soultanova 2005). This model of labour mobility, in a modified version, was preserved in the Balkans during the following historical periods.

The Rudari, who consist of two groups of Lingurari ('spoon-makers') and Ursari ('bear-trainers'), started arriving in what is today Bulgaria from Wallachia and Moldavia in several waves, the majority of them coming during the 19th century. The mother tongue of both groups is Romanian and they are traditionally Orthodox Christians like the majority of population in Bulgaria. Nowadays, some of their representatives, mostly women, convert to Protestantism. Religious conversion to Evangelical Christianity in the post-socialist period appears to be a widespread phenomenon among Bulgarians also (Slavkova 2007).

Both groups had practised a semi-nomadic way of life in the near past, but Lingurari and Ursari had not travelled together. Several families of relatives led by a leader, whose task it was to contact the local authorities, had travelled in the villages of Bulgaria. While traveling, the Lingurari sold their wooden articles (spoons, ladles, troughs, spindles etc.) to locals to provide for their families. The 
Ursari had bears performing to the sounds of the tambourine or the rebec at various fairs and markets. The seasonal movements were strongly related to the practicing of their traditional occupations and they crossed the borders of Bulgaria extremely rarely, although, in some cases Ursari practiced nomadism over long distances. At the end of the 19th century some of them went with their bears to "make money" in Istanbul and even in Anatolia. The Rudari settled down mainly between 1940s and 1960s. During the "epoch" of Socialism (1944-89) they were workers in different cooperative farms and factories. Due to the availability of credit for housing provided by the state they had their own houses.

During the socialist era for the first time the Bulgarians and Rudari, being part of one socialist society, began to employ similar economic strategies. Transnational economic travels included work in destinations inside or outside Europe (the Central European socialist states, East Germany, USSR, Libya, Cuba, etc.). This was, however, a state project subject to the Communist Party's permission to leave and to the approval of the host destination, and only very few actually travelled abroad. Nearly all of them (Bulgarians and Rudari) worked mainly as construction workers, drivers, etc. Another small group of people with various specialties (musicians, athletes, artists, interpreters, etc.) had also the opportunity of working on contracts abroad. For example, in the 1980s a woman from Sofia lived for three years in Cuba, where she worked as an interpreter. Nowadays, she lives in Madrid and works as a housemaid.

After 1989 the families of those Bulgarians and Rudari who previously had been abroad were among the "pioneers" who initially went to Germany, the Czech Republic, Israel (as construction workers or service staff), and then to the Mediterranean countries. The main differences between the out-migration of Bulgarian citizens during Socialism and those after 1989, besides the differences in preferred destinations and different attitudes and motivations towards crossborder traveling observed among the migrating people, is that the traveling before 1989 was subject to strict state control and was not expected to have the aim to settle permanently in the destination country, as opposed to after 1989 when they emigrated to the new destinations. 
Timeline and Mapping of the Migration to Greece and Spain

Greece and Spain are typical examples of the destinations of Bulgarian and Rudari migrant clusters, often founded by illegal workers, who later legalized their situation and were joined by their families. According to different media sources, the unofficial number of Bulgarian citizens altogether in both countries is about 500,000 to 550,000 people. $^{1}$ The process of formation of the communities in both countries has its own specifics although the economic motivation for emigration was the same in both cases.

The collapse of the socialist regime in Bulgaria has caused the emergence of a new migration pattern which has not been popular before, namely an east-south move from Bulgaria to Europe's Mediterranean countries. Bulgarian citizens leave their motherland as part of the mass emigration to the EU countries. Generally speaking, Bulgarians' motivation for emigration was related to the drop in their living standards after 1989. Many Bulgarians lost the prestige of the social positions they used to enjoy during socialist times. The aim of some other individuals going abroad was not only to earn more money but to see "how the Westerns live" or "to try their luck" and find better opportunities for themselves abroad. The reason why the Rudari began to travel outside the country after 1989 is that most of them remained jobless and by undertaking this "journey" they tried to adapt to the new social and economic conditions. The motivations for emigration as well as the preferred countries of destination are geographically determined and depend also on circumstances such as state control over borders, salary rate, the attitude of employers or locals towards foreigners. A very important reason to choose Greece and Spain was the possibility to find a job relatively easy and quickly, although one had to accept jobs including manual labour at first. They were also attracted by the possibility to settle with all the members of their families and, last but not least, because of the existing perception among Bulgarians that there was a similarity between Bulgarians and the Spaniards in terms of their way of social living, on the one hand, and Bulgarians and Greeks in terms of their religious belonging to the Orthodox Christianity, on the other.

Greece became a preferred destination for migration immediately after 1989 due to its geographical proximity to Bulgaria and the low 
costs in getting there, while Spain attracted them more in the late 1990 s, one of the reasons being the higher salary rates there. Spain is quite far away from the Bulgarian territory, the journey there by coach, as the initial means of transportation of the migrants, lasts 2-3 days. The migrants went abroad unprepared and had no idea of the style of living there. Some of the people left for Spain and Greece without a command of the language. Others attended private lessons in Spanish or Greek, or studied the language at home on their own using "teach yourself" books. There were, however, educated people who had graduated language schools or had completed university degrees in languages (Spanish, French, English, Greek, etc.), which gave them some advantage in the quick mastering of the local languages. An important reason for the Rudari to prefer Spain was the proximity of their mother tongue, Romanian, to Spanish.

The migration towards Greece and Spain could be divided into three main stages - 1989-2001; 2001-2007; and from 2007 on. The first period started with the end of the socialist regime and contributed to the emergence of mass emigration to the West in ways and forms previously unknown in Bulgarian history. Travels were limited by the states with financial restrictions and visa requirements, although, these were not insurmountable obstacles to those who really had decided to work abroad.

The composition of migrant groups was heterogeneous, which was related to the fact that these people had different social, educational and ethnic profiles. The first group, which was the biggest one, consisted of illegal workers who were temporary migrants (the so-called gurbetchii) and who left with an intention to "make some money" and go back to Bulgaria within a couple of years. However, most of them stayed much longer. This group included representatives of different ethnic and religious groups (Bulgarians, Turks, Bulgarian Muslims-Pomaks, and Gypsies) and all of them developed a model of labour mobility similar to the traditional gurbet. The representatives of the Rudari group were a considerable part of those gurbetchii. They led the emigration wave of the Gypsies towards Greece and Spain. This is not a unique case and some other Gypsy groups from Bulgaria established their own regional migration networks, for example, as was the case with the Turkish Gypsies from 
North-eastern Bulgaria who migrated to Poland, where they often work as traders to sell clothes and footwear (Erolova 2010: 52-57).

There was another small group of migrants (mainly ethnic Bulgarians) both with training and professional competences (musicians, medical staff, sport trainers, teachers, philologists, writers, painters, etc.) who went abroad with enough information about the country, with knowledge and with better prospects of a future career development, sometimes even with a work contract in hand. Some of them were also illegal and started doing, like gurbetchii, unqualified jobs, but they had the greatest prospects of finding prestigious work. Many of those Bulgarians who arrived in the early 1990s in Spain and headed for Madrid and Barcelona came from the capital city of Sofia unlike those who went to other cities (e.g. people from Gabrovo and Russe in Northern Bulgaria went to Athens in Greece, etc.)

One of the most common ways to get to the destination before 2001 was by coach or through the use of the so-called "traffickers" who drove their passengers across the border in vans. In the 1990s, it seems that the Rudari who went to Greece quickly figured out a way to reach their destination, as the clandestine border crossing using small paths appeared to be a common occurrence. Another popular way of traveling prior to 2001 was by using a tourist visa to Spain or Greece that guaranteed a legal passage through the border checkpoints.

The very first destinations for Bulgarians and Rudari in Greece were Athens, Thessaloniki and Crete; Madrid, Barcelona and Valencia in Spain, where they expected work to be most available. According to the data of the Address Register of the National Statistical Institute of Spain, in May 1996 their total number was 1,231. ${ }^{2}$ Bulgarians and Rudari from Northern Bulgaria were the most active in their trips to Spain, those from Southern Bulgaria usually went to neighbouring Greece.

In the late 1990s, we find more heterogeneity in the migration flows regarding the places settled to abroad. The Bulgarians settled in small rural towns of provinces near Madrid, Valencia, Barcelona and started to settle also in other regions (Castile and León, Andalusia, Murcia, Aragon, Canarias, etc.). Rudari headed for settlements in 
the regions of Madrid, Castile-La Mancha (Cuenca, Albacete), Castile and León (Valladolid, Segovia, and Burgos), Murcia (Murcia, Cartagena), Aragón (Zaragoza), Catalonia (Barcelona, Tarragona, and Girona). In Greece, the Rudari and the adjacent Bulgarian population headed for settlements in the regions of Thessaloniki, Katerini, Kavala, Komotini, Volos, Larisa, Patras, Athens, Chania and Iraklion. The migrants headed for destinations where they already had relatives or friends who could help them adapt, find a job and a place to stay. All settled in migration quarters, because of the lower housing costs or in villages near the cities, where they expected to become integrated into the local community. These destinations were the favourite ones also because they provided enough available jobs in the sphere of agriculture, tourism and social and domestic services.

In 2001 Bulgaria was removed from the "black Schengen list", which lifted the visa regimes with Greece and Spain. After that year the number of people leaving changed considerably. In 2001 the Bulgarians in Greece numbered 35,104 people, according to the data provided by the population census (Stanchev et al. 2005). In Spain, Bulgarians already numbered 12,413 and in the coming years their number increased drastically reaching the number of 168,997 in $2013 .{ }^{3}$ After 2001, however, there seems to be a greater number of women among migrating people and they emigrate on their own in search of work (Fakiolas and Maratou-Alipranti 2000: 101-117; Macías 2003: 247-268). Despite the fact that in many cases women were the first to leave, it was a matter of a family strategy or planning, while cases of women departing on their own (widows, divorced or single women) with the wish to start a new life in the foreign land without relatives following them were very rare (Slavkova 2012: 443-462). Review of the official statistics in Spain revealed that the women were equal participants in the migration process and that their number did not exceed that of men. The opposite case is illustrated by Greece, where the predominance of women is more typical (Rangelova 2006). This is due to the fact that Greece is a neighbouring country and it is much easier to go and work there.

The means of transportation also changed. More people started travelling by air. Among the Rudari the transition from the "no- 
madic times", when certain families or groups of relatives travelled together with carts pulled by horses or donkeys from one village to another, to travelling by plane to Spain, brought about a number of dramatic changes in their life. Before 2001, it seemed that the workers were sojourners rather than settlers in that they all regarded their stay overseas as temporary. After that year, the transition from seasonal mobility of cross-border labour to emigration occurred. It happened with the birth of children of migrants, or when their children born in Bulgaria joined them and had to start school or socialize in the new surroundings.

Since 2007, Bulgaria joined the European Union and Bulgarian citizens have been able to travel freely to Greece and Spain with only their IDs. After that year people continued going to both countries, but the intensity of migration is much smaller than in the previous period. This is not the case, however, with the emigration of Bulgarians to the UK, which is a relatively new phenomenon that has become a massive movement after the admission of Bulgaria to the EU (Maeva 2010: 173-195). Meanwhile, the Spanish and Greek governments reasoned that Bulgaria's membership into the EU would translate into large numbers of migrants. Thus, this resulted in their imposition of a moratorium on the entrance of Bulgarian workers until 2009.

Currently, Bulgarian citizens have legalized their status in both countries. Bulgarians and Rudari are successfully incorporated into the social and cultural spaces they live in both in Greece and Spain, regardless of the fact that they are foreigners and only a few of them have Greek or Spanish citizenship; Jasna Čapo found the same for Croatian economic migrants to Germany (2008: 324). Since 2008-2009, with the global economic crisis, part of the Bulgarian and Rudari families started returning to Bulgaria, due to their unemployment; some of them planned to stay temporarily in Bulgaria and wait for the crisis to go away, while others decided to return permanently.

In Bulgaria the development of the out-migration to the Mediterranean coincided with the end of socialism and the collapse of the social and economic order that had been in play for forty-five years. From the early nineties to the present day, east-south moves constitute a practice that encompasses hundreds of thousands of people and 
its effects cannot be reduced to its impact on demographic characteristics within both the countries of origin and of destination. Migration constituted for them both a goal and a road towards the transformation of the pre-existing way of supporting their families and towards the adoption of new modes of social relations and community building.

\section{Social Ties of Bulgarians and Rudari}

Two types of social ties are widely discussed in the theoretical literature - strong (or bonding) and weak (or bridging) ties. Strong ties prevail in families and among people who have intensive blood or emotional bonds, while weak ties are not based on family, blood or emotional bonds. They can be formal and represent links to more distant persons. Type of capital that can be acquired by the group members of networks with prevailing strong ties is bonding social capital, and the group members of networks with prevailing weak ties can obtain through their contacts bridging social capital, respectively. Mark Granovetter's paper “The Strength of Weak Ties", published in the 1970s, is an influential sociology article in which he argues that the strength of the weak ties is an important factor to individual's opportunities for occupational attainment and to its integration into communities. He states that the spread of information in social networks depends on the type of prevailing ties and only weak ties may be local bridges. The people who maintain such social links could be provided with the necessary information and influence in job searching. Weak social ties have a cohesive power, whereas strong social ties breed local cohesion but lead to overall fragmentation (1973: 1360-1380).

The analysis of social capital and a theory related to the social networks to which individuals and small groups have access emerged from the works of Pierre Bourdieu (1980: 2-3; 1986: 241-258) and James Coleman (1988: S95-S120). They emphasize the expedience of closed networks (that with prevailing strong ties). In his paper, Coleman does not mention the works of Pierre Bourdieu, although some parallels exist in their analysis of social capital, and proposes that social capital helps produce human capital (1988: S95-S120). 
The second trend discussed in the theoretical literature is that related to the community being seen as unit of analysis rather than the individual connections used to achieve certain ends. It emerged from the work of Robert Putnam (1993: 35-42). According to Putnam, bonding social capital develops through in-group ties, such as those based on ethnicity, whereas bridging occurs across social segmentation. Bonding social capital is good for undergirding specific reciprocity and mobilizing solidarity. Dense networks in ethnic enclaves provide crucial social support, and bridging networks, by contrast, are better for linkage to external assets and for information diffusion. However, under many circumstances both bridging and bonding social capital can have powerfully positive social effects (2000: 22-23).

In the case viewed in this paper, the Bulgarians, along with the Rudari, joined the common migration flows from motherland to Greece and Spain. The birthplace of the Bulgarian nationals abroad is important insofar as that the people of a given region in the motherland are involved in the same regional networks in Greece and Spain, and as a result of it they settled down even in the same locality. People in these regional migration networks are relatives, neighbours and friends or people connected by strong family and emotional links, and settling together provides them with solidarity and support in the process of social adaptation. However, Rudari created their regional migration networks, whose members are relatives, along with those involved in the common migration flows. They manage to sustain some kind of distinctive identity as an ethnic community within the migration flow, mostly by forming groups of people from the same regional group and place of origin when they settle abroad.

Upon arrival, ethnic and religious self-awareness of the individuals and groups are maintained but family, neighbour and friend ties, which have been already created in the homeland, became more significant in the formation of the social circles of the Bulgarian and Rudari migrants. These social circles are also influenced by the relationship patterns that the migrants initiated with the population of the areas where they settled and social resources they received from them (contacts with other local people). In other words, all Bulgarian nationals (Bulgarians and Rudari) maintained the social 
resources of strong ties that they have with the people with whom they travelled together, but then create bridging ties with the local population and other immigrants.

\section{Social Ties of Relatives}

The Bulgarians and Rudari develop similar labour activities which they use to adapt to the new social-economical milieu. Rudari do not look so different from the Bulgarians in their styles of living and working. The money factor is the most important one for every migrant leaving to work in Greece and Spain regardless of their ethnic belonging. Because of this, initially only one member of the family of the Bulgarians and Rudari or a pair (spouses, two brothers, two sisters-in law, etc.) went abroad, in order to be able to find a job more quickly. After that, the most popular model is that the parents live abroad together with their working age children, while the elderly, who look after the smaller grandchildren, are left behind. The final stage in the migration from Bulgaria to the Mediterranean is that all family members leave. In some cases, the elderly also go abroad. In other cases, they stay in the homeland and the children are sent to them for the winter or summer vacation.

Regardless of the fact that the family members may have gathered to live together for a long time, they perceived their stay abroad as temporary and, because of this, saved money to improve their living standard back home. As George Gmelch found for Barbadians who left Barbados and emigrated to the UK and North America following World War II, most of them only planned to stay away long enough to save money to buy a house and perhaps a car (2004: 206-225).

Upon arriving, the job-hunting strategy of the Bulgarian citizens in Spain, which consists of going around companies asking for a job using the simple words busco trabajo ("I am looking for a job"), is similar to the one observed by Cristóbal Mendoza among the Africans in Catalonia (2001: 41-66) because newcomers do not have access to information about the possibly available jobs. They begin working as farmers, domestic helpers, or as unskilled workers in construction, because of their lack of language expertise, papers and support from the locals. It appears that in the sphere of agriculture, where employment is seasonal, some Rudari "revived" their 
seminomadic way of life, which they had practised in the past, and, in some exceptional cases, their mobility became transnational. A good example of employment in agriculture is the Rudari family who arrived in Greece in the early 1990s and began seasonal work in the northern part of the country where the family lived in tents during the working season and had permanent winter lodgings. In autumn, they lived and worked in Chalkida (Euboea island), where they picked grapes, for winter, they moved to Sparta (Peloponnese peninsula) or to Karditsa (Thessaly), where they harvested olives or peppers; in spring they moved to Katerini, where they picked strawberries, while during summer they worked in Veria (Central Macedonia), where they picked peaches. In another case, the families of two married sisters lived in Northern Spain during the agricultural season and worked in farms. In the cold season, they moved to Greece, where men worked in the construction sector and women in a factory producing sweets.

Quite often the Bulgarian and Rudari women began working as domestic service workers. The sphere of social and domestic services is "reserved" for migrant women and is a "gateway" for them to get included in the labour market (King and Zontini 2000: 35-52). Men manage to find work as unskilled workers in a limited number of areas - construction, transport and agriculture. Another type of job for which women are seen as more suitable is kitchen assistants, cooks, shop assistants, workers in factories or in the sector of tourism. Indeed, work as cleaners in the homes of Spaniards or Greeks is accepted by the Rudari as temporary work and they quickly tried to find another job, such as work in taverns and restaurants, hotels or factories. Some of the Bulgarian women also manage to break free from the "vicious circle" of social and domestic services and find a better job using the family-and-friend networks or using their former qualifications. Men usually hold second jobs in construction, as drivers, mechanics in garages, technicians, etc. Some Rudari men found jobs in different carpentry warehouses, which is associated with their skills of making various articles out of wood.

The common pattern is that, wherever they go in Spain and Greece, people communicate first with the members of the group with whom they travelled. In the first stage of their arriving, the Bulgarians and Rudari preserve the boundaries between them, although sometimes 
they may occasionally have neighbourly contacts when settling in the same neighbourhood. The interaction with Bulgarians or with Rudari is limited; the Rudari respondents' explanation is that they cannot trust the Bulgarians for fear of being cheated by them or because the Bulgarians are perceived as very envious and as people who do not support each other. The Bulgarian respondents' explanation is that "with Gypsies it is better not to deal at all".

The members of the Rudari social circles are only relatives of the respective regional group, while these of the Bulgarians could include relatives but also friends or neighbours from the birthplace. Several families form the large Rudari kin unit called jins. Solidarity and support exist toward the family and other relatives who are part of the jins. Rudari economic decisions and entrepreneurship take place within the circle of families and kin unit. The Rudari maintain their social life by, for example, several families going together to a restaurant in the weekends, or to a picnic, men angling together or organising weekly football or volleyball matches. Also, Rudari in Crete, more often women, visit a Greek Pentecostal Church and a Rudari Church of Jehovah's Witnesses and after the end of the religious services sometimes drink coffee together, chat, share information about job availability or discuss matters concerning the life (or of a member of the community).

It is mostly with the help of contacts of their relatives that the Rudari can rely on finding a job, unlike the Bulgarians, who rely on their friends, too. In the case of Greece, the Bulgarians can find work at the private employment agencies called grafia. As Nikolay Gabărski notes, Rudari in Greece have relatives all over the country, they have close social ties with them through which they receive regular information where and what type of jobs are available and how much they pay. Therefore, they are much more mobile than the Bulgarians and rarely use the services of employment agencies (2008). In Spain, Gómez-Mestres and Molina pointed out that the Bulgarian social networks in Catalonia are based on kinship ties and not on the ethnic or religious communities, among which the most important are those related to the closed circle of parents (GómezMestres and Molina 2010). Although this is indeed the case, we will point out further examples of creation of ties outside the ethnic group and the kin unit, based on shared nationality or religion, and those of mixed marriages, which are examples of extension of ties 
beyond the boundaries of the traditional (closed) community. The most important family gatherings, that cause cross-border travelling in order for relatives to be together, are weddings and funerals. These are held both at home and abroad, but more often the dead are buried in the motherland.

\section{Social Ties between Compatriots}

Reproduction of community life abroad, maintaining ties between relatives away from the motherland, and also the creation of new relationships outside the ethnic community demonstrate group flexibility and ability to adapt in a milieu different from their original one. A second circle of communication and sharing of everyday practices or exercising solidarity in search of a better job, for example, is created among the people from Bulgaria. Surely, relatives tend to rely first on each other when looking for a job or when in need of money; the second scenario is relying to their compatriots. After several years of living in Spain and Greece, part of the families changed their migrant strategy. Gradually a number of families bought flats in Spain on credit, however, most migrants in Greece still live in rented dwellings. In time the money they earned was used to pay off the housing credit, for education of the children, the coverage of the monthly expenses and for holidays in Bulgaria. However, the intention to return to Bulgaria remains in an uncertain future. Some informants said they intended to stay abroad until they retired.

An option for migrants that could guarantee them a more stable income was to register as self-employed and thus create an economic niche in which they could develop their own small- or medium-sized business. It gradually evolves into a small business that employs relatives - in that way the profit stays in the family circle. But compatriots can also be employed. In Spain and Greece, the Rudari were more entrepreneurial, more than they had been at home, although the men continued to be afraid of doing "big business", as one interlocutor said. Like other Bulgarians, they established family businesses and opened restaurants, bars, disco clubs, shops for Bulgarian staple foods, phone centres (in Spain), construction companies to carry out small building repairs for the surrounding Greek or Spanish population. In addition to doing business, these 
are all places where social ties with other Bulgarian citizens are maintained as they can meet and exchange information about possible job vacancies. Contrary to this, even though the above-mentioned social places are quite popular with the Bulgarian citizens, some of them could not consider them good places for social contact because they were also sites of sharing local gossips. Such locations in Spain are small phone centres, where migrants can make phone calls to their home country at a cheaper rate, use the Internet, send money or parcels to their relatives back home. They are also places where Bulgarian citizens from different ethnic origins meet, talk and maintain social relations among them. There is, for example, a Bulgarian locutorio ('phone centre') in Northern Spain. In the square in front of it, Rudari and Bulgarians meet at weekends to chat, share problems or tell about their week.

Bulgarian citizens continue to differentiate themselves on the basis of their ethnic, regional or religious belonging. Bulgarians do this when they speak about Gypsies in general or when they are involved in an interpersonal conflict. The popular expression tsiganska/balgarska rabota, literally “a job Gypsy/Bulgarian style”, and meaning a shoddy piece of work or a work done without sufficient effort is used to describe the above-mentioned differentiations. The existing personal conflicts, however, confirm the idea that Bulgarian citizens see themselves as members of the same community and the social resources received by them are used to achieve certain shared ends. In everyday life, new friendships and good relationships among neighbours and co-workers are created regardless of their different ethnic origins. On that basis, Bulgarian citizens are inclined to help each other no matter whether they are ethnic Bulgarians or Rudari. A visit to a doctor causes more anxiety to migrants because they cannot always explain how they feel in a foreign language. There is a tacit rule that when it comes to health the migrant cannot refuse to help the needy, whether they are Bulgarian or Gypsy (Rudari). The patient is always accompanied by a relative or someone who knows Spanish well (could be Bulgarians, as well) and will assist in the conversation with the medical staff. 


\section{Development of Collective Integration Strategies}

To support the social integration of its members into the new socio-economic and cultural environment and to facilitate their transition from mobile workers to settlers, the Bulgarian community creates its own structures. It creates associations and schools, which represent them as a foreign group in Greece and Spain, and as Bulgarians before the Bulgarian authorities. These structures also serve to organise the social spaces and affect the community building. Community comes first in the minds of the representatives of these structures, they are the ones who will be able to interact successfully with people within the Bulgarian migrant community and with representatives of the local institutions. However, these representatives constantly have to defend their influence among their compatriots by taking care of them, because their position is a matter of negotiation with the community's members. In Spain there are over 55 and in Greece around 10 associations and Sunday schools. $^{4}$

The associations and schools develop educational activities and promote cultural events. The principle of their functioning in Spain is following: first an association is established and, after that, a Sunday school is opened attached to it. The reason is that the migrant associations are able to apply for funding from various institutions in Spain and their cultural and educational initiatives are supported by the authorities in the autonomous communities. The principle of operation of associations and schools in Greece is different. Migrant organisations exist usually in the form of the Greek-Bulgarian cultural associations because the activists can use the resources of personal contacts with Greeks for their purposes. An organisation can establish its own Sunday school but a school can also be founded without the existence of an association. In most cases in both countries, these are led by women with university degrees. In Sunday schools, Bulgarian language and literature are taught, also Bulgarian history and geography; extracurricular classes are held in applied and stage art, folklore singing and dancing. They target all children from Bulgaria, regardless of their ethnic origins. The Rudari children, for instance, go to Spanish schools as well as actively attending the Bulgarian schools and sometimes they make 
up almost the entire class. In Greece the situation is different and they rarely attend Bulgarian classes and go only to Greek schools.

The social relations among the members of the Bulgarian community that are created around the Sunday school and association can be described as never-ending interactions and oppositions, because in one moment they could help each other out and express solidarity, and in other moment they could be involved in personal conflicts. Although several personal conflicts could arise, both types of organisation should be understood as a social structure that opens possibilities for the previous social relations to be maintained and new social relations with fellow citizens to be developed. Thus, the migrants have access to social resources, which are based on common good with people of various social, ethnic and religious origins. James Coleman explains that social capital inheres in the structure of relations between actors and among actors; it facilitates certain actions of actors within the social structure and makes possible the achievement of certain ends (1988: 98).

Sunday schools established in Spain are often subsidised by Spanish institutions by way of providing funding for projects put forward by the Bulgarian organisations, which is not, however, the case in Greece. There is a trend towards better cooperation among organisations and schools within the same Spanish autonomous community due to the geographical proximity, and the fact that they have access to the same resources and communicate with the same institutions. However, the associations and the respective schools in Madrid and Valencia have imposed themselves as umbrella organisations for the entire community, they are the most proactive and try to attract the activists from other regions, contributing thus to the unification process on a supraregional level.

In Greece, the collective initiatives of the migrants, related to the preservation of Bulgarian culture and language, is influenced by the Greek ideology of the nation-state oriented to the preservation and promotion of a unified Greek national identity and culture (Kaurinkoski 2010: 119-139). Bulgarian activists in Greece can rely on the help of their Greek friends and colleagues but rarely on the institutional support. The Bulgarian school in Thessaloniki, for example, has the status of a religious school and some extra classes of religion are provided for the students. Its director is of Greek origin 
and the teachers are Bulgarians. For both countries, the creation of the national programme "Native language and culture abroad", with which the Bulgarian state began providing financial assistance for the schools starting from the academic year 2008/2009, helped open more Sunday schools.

The structures that primarily nurture the development of bonding social ties are the Orthodox religious societies. In Spain and Greece, there are several church communities with priests appointed by the Bulgarian Orthodox Church. Compatriots gather there on religious holidays such as Easter, St. George's Day or Christmas or for family celebrations, such as the case of Rudari in Northern Spain who organised a big celebration for baby christening and a Bulgarian Orthodox priest from Madrid was invited to perform the ritual. In contrast, religious societies of Evangelists, whose meetings take place more frequently (several times a week) than those in the Orthodox communities, they are more informal and create an intimate religious atmosphere, providing opportunities for keeping the previous strong relationships and for creating bridging ties. They reflect the overcoming of ethnic differences and social segmentation between people from Bulgaria because of the common faith.

Cultural activities developed by the associations focus on various events such as celebration of Bulgaria National Day, March 3rd, Cyrillic Alphabet and Bulgarian Educational and Cultural Day, May 24th or common Bulgarian holidays such as Baba Marta ('Grandma Marta'), March 1st, etc. The celebrations of some holidays are more ostentatious in Greece and Spain than they used to be in Bulgaria. In addition, the associations in Spain promote pan-Bulgarian events such as, for example, the first convention of the Bulgarians in Spain held under the motto "All the Bulgarians Together" organised by AIBE Balcan in Madrid and that brought more than 4,000 Bulgarian nationals together. Over the years, the organisations have put other programs in place - they raise money for and help build social homes for children in Bulgaria.

The Rudari in Spain are more active than those in Greece by being engaged in various associations of Bulgarians and by forming their own organisations. Behind this is a desire to establish their identity as Bulgarian citizens. The enhancement of their Bulgarian national identity does not remove existing boundaries between the ethnic 
groups, or different forms of "otherness", but rather exists along with them. The activities organised by the Rudari associations can be regarded as a strategy of the group to maintain solidarity and sociability between the members. For example, in Spain the Tsar Simeon federal structure, comprised of several Rudari organisations, whose leaders are relatives, has its annual gatherings under the motto of official meetings of Bulgarian citizens abroad, but it allows the members of the Rudari group to socialize and to maintain their group identity. Furthermore, the president of the Rudari federation looks not only after his own community, but after all the Bulgarians. He runs educational, cultural and social work for the entire community - for instance, he held a football tournament for immigrant youth in Spain and runs a Sunday school for Bulgarian kids. The situation in Greece is different from that in Spain and the Rudari in Greece stay, to some extent, away from the intercommunity organisation of the Bulgarians and do not form their own organisations.

\section{Cross-Cultural Social Ties}

The life in the new social milieu is a basis for establishing ties with locals or with other migrants. Thanks to various social ties that they create with the local population, Bulgarian citizens begin to become part of the local society regardless of the fact that they are included in it as a foreign community. Along with that they are included in various social circles of fellow citizens; each of the members might be incorporated into the social circles of Spaniards and Greeks as well. The new contacts outside the group found at the workplace provide a source of information about possible available jobs and become a source of support in the context of migration. At times, when Spanish employers trust the migrants, they could help the next wave of arriving relatives find a job. For instance, at a construction company a father, his son and his nephew work together, while the wife and the daughters-in-law work as nannies and maids in the house of the Spanish owner. Having the support of the local people is important to the Bulgarians because they will always remain foreigners.

In organising the Rudari weddings in Greece, for example, some changes occur. Engagement is usually originated in Bulgaria and 
after that, a civil ceremony is concluded. The wedding celebration is organised abroad and Greek colleagues and friends are also invited as guests.

Mixed marriages are one of the results of the influence of the local environment on the group's social cohesion. The intermarriages can be seen as a strategy for adaptation and integration into the new societies. In Spain, mixed marriages are still rarely the case, both among Bulgarians and Rudari. By tradition, marriages among Rudari are concluded within the regional group and mixed marriages are not considered successful. Traditionally mixed marriages are those with a representative of another regional group, with representatives of Ursari (although there are examples of such marriages), with Bulgarians or other Gypsies. Under the terms of migration, the intermarriages with members of other regional groups who live abroad in the same or in the neighbouring villages, and with foreigners have become more frequent. In Greece, several examples of co-habitation between Greeks and Bulgarians can be found as well as of intermarriages. For example, the headmistress of one of the Bulgarian schools in Greece lived with a Greek man, which for both of them was a second marriage, and in another case a Bulgarian school teacher was married to a Greek man, whom she met while they were studying together in Bulgaria. In Greece, marriages in a form of co-habitation with Greeks are more common among the Rudari, especially if they were both already divorced. For example, the sister of my interlocutor had a second marriage with a Greek man, who owned a hotel on Crete.

An interesting point is whether there are mutual relationships between the Rudari and other Gypsies (local Spanish and Greek Gypsies or Romanian Gypsies from Romania), as well as between Rudari and Romanians from Romania. The Bulgarian Gypsies, including the Rudari, are in absolutely no contact whatsoever with the local Spanish, Greek or foreign migrant Gypsies. The living standards of Gitanos (or Calé/Calos) in Spain, for example, are higher than those of the Gypsies from Eastern Europe, and they occupy their specific economic niches and do not have professional or other contacts with the Gypsy migrants. In Greece, there is a local Rudari population, and the Bulgarian Rudari often had neither heard about them, or if they knew about them, they thought 
they had nothing in common because in comparison with the local Rudari they felt more Bulgarians. This applies also to the Romanian Gypsies, whom the Rudari perceive as beggars and nomads, and with whom they do not want to deal. This is also the case with the Rudari, who, while living in Bulgaria, demonstrate an identity of Rumanians (old Rumanians), but during their stay in Spain and Greece present themselves as Bulgarians in front of Spaniards and Greeks, not in the meaning that they change their previous identity, but for the reason of that through comparison with the Romanians from Romania they realize that they are totally different from them. According to the interlocutors, the Romanians from Romania were worse workers and thieves and that is why nobody wanted to be identified as one of them. For example, my interlocutors from Crete were neighbours of a Romanian family. They did not maintain any contact with them and to my question, why they did not communicate with them, they told me that they "felt as Bulgarians and there was no need to communicate with Romanians". The contacts between Evangelical Christians present us creation of another type of social relations. The only Gypsy migrants or local Gypsies with whom the Rudari could have had certain are other Evangelists with whom they visited the same church. However, it seems that the Bulgarians and the Rudari are more likely to maintain contacts with local people and other immigrants than with Gypsies within the Evangelical communities, considering that these ties would be beneficial to them.

Contacts with other migrants are usually limited to co-workers. Of course, there are examples of friendly contacts with other foreigners, but it is an interesting fact that Bulgarians and the Rudari create more friendly contacts with the local people and rely more on their support, which is a form of adaptation into the host society. People from the Balkan countries and those from the former socialist countries are presumably perceived as being closer than other migrants and they could be housemates if they live in shared accommodation. Marriages between Bulgarians and these migrants are concluded rarely, but there are some examples. The Bulgarians and Rudari have almost no contact with migrants such as Latin Americans, Africans, Moroccans or Pakistanis other than in cases where they happen to live in the same neighbourhood, work in the 
same construction company or go shopping regularly in the same Chinese stores, which are widespread in Greece and Spain.

Bulgarian associations and schools construct social spaces where compatriots can maintain contacts with local people. In Spain, they strive to promote Bulgarian traditions to the native citizens, and help people of Bulgarian national origin become a part of local society. In Greece, due to the lack of official support for migrant activities, organisations try to maintain the specific Bulgarian traditions within the frames of Bulgarian community and express their distinctiveness from Greeks. On the other hand, referring to the same Orthodox religious belonging with Greeks, they demonstrate their closeness to them. Participation in festivals and fairs organised by the Spaniards is an essential part of the work of the organisations. There the culture and traditions of the various migrant groups are presented and they are part of the state's policy for inclusion of the immigrants into the community life of the Spanish people. The Bulgarians regard participation in those festivals as a privilege of being invited and also as an expression of the wish to pass for a united community that is no less important for the Spanish society than the rest of the migrant communities. In the recent years, at the cultural events on various occasions, organised by Bulgarian associations in Spain, different folk dance groups perform and invitations have been sent out to members of the public and representatives of other migrant groups such as Romanians, Ecuadorians, Russians, etc. In her article, Caroline Brettell also discussed various organisational spaces constructed by Asian Indian immigrant population in the United States through their voluntary (regional, religious, ethnic, etc.) associations. The organisations within the Indian community demonstrate various ways in which immigrants can draw on different dimensions of bonding and bridging social capital to express both their distinctiveness from and their affinities with the host society (2005: 853-883).

\section{Identity Imaginations}

When it comes to Bulgarian citizens in Greece and Spain, it also appears that the new environments in which they live influence their ways of identification. The main feeling of all Bulgarian citizens abroad is the one of belonging to the Bulgarian migrant 
community, regardless of differences in their ethnic or religious affiliations. These members think and act according to the position they occupy within the community. They define their neighbouring communities (the majority and migrants) in ethnic dimensions (Spanish and Greek people, Gypsies, etc.) and also by the country of origin - Spaniards, Greeks, Romanians, Ecuadorians. Under the terms of migration the process of identification as Bulgarians/ Bulgarian citizens is enhanced and one of the reasons is that they feel attached to their homeland. Unifying effect not only causes the tendency for them all to declare themselves as Bulgarian citizens, but also the fact that they are "imagined" as a "united" Bulgarian community by the surrounding Spanish and Greek population (Anderson 1991).

There are two different trends in the way of identification as Bulgarian citizens. One of the trends is that they feel proud of being Bulgarian nationals; they send their children not only to the Spanish and Greek, but also to the Bulgarian school, they speak Bulgarian at home, watch Bulgarian TV, etc. There is another tendency, which is more common among the Bulgarians than among the Rudari, where they demonstrate to the other compatriots that they are better integrated and belong more to the Spanish or Greek communities than to the community of migrants from Bulgaria. They declare to the other Bulgarians that they are "more Spanish or Greek than them". This feeling of belonging to the local society they express in various ways; sometimes Bulgarians say they avoid communicating with the other compatriots, because relations with them bring only trouble and prefer to stay in touch only with locals; that is also why they sometimes say that there is no need for their children to attend Bulgarian classes or to speak Bulgarian, because they would not return home and knowledge of mother language would not be useful. This is an expression of the migrants' wish to be integrated into the local society more quickly. Life in a foreignlanguage environment and the linguistic proximity of the Spanish and Romanian languages gives the Rudari from Bulgaria a reason to feel that they share common origins with the Spanish. 


\section{Conclusion}

The text developed a comparative perspective in the experiences of the Bulgarians and Rudari in the migration contexts in Greece and Spain. After 1989, the emigration of Bulgarian citizens to the EU countries occurred as a widespread phenomenon. As part of it, another great migration flow formed in the $1990 \mathrm{~s}$, this is the eastsouth move to the Mediterranean countries. These were recognized by many Bulgarian citizens as possible countries of destination and later became a "second home" for them. The contemporary Rudari migration pattern is similar to the pattern of Bulgarians, and one of the main reasons for this is the fact that as Bulgarian citizens they are part of the Bulgarian society. The transnational movement has very important economic and social functions: by travelling, the communities could sustain their families and could develop their social group organisations. The emergence of migrant clusters is one of the main results of the transnational labour migration. As a result of the communities developing in both countries, Bulgarian citizens introduced various collective strategies for establishing associations and schools by which they tried to position and shape their traditional relationships within the new society, thinking that this would be a way for successful integration. Orthodox communities create conditions for religious practices, which are associated with community building, to be developed and for strong relationships between migrants to be maintained, but Evangelical societies have an important role in reinforcing the bridging ties between compatriots with different ethnic origin.

There are some similarities as well as differences between the social adaptation strategies of migrants in Greece and Spain. Both countries attracted families who believed that there they could adapt successfully and start their lives afresh. In Spain, Bulgarian citizens develop various collective integration strategies on a larger scale and have greater political influence on the Bulgarian community there. In Greece, the communal way of life of Bulgarian citizens is less organised and on a smaller scales due to the social and political contexts there related to attitudes towards foreigners and the politics towards their integration. It also appears that in the Spanish case, the Rudari are successfully included into the community life of the Bulgarians and that they develop the same 
integration strategies, while in the Greek case they remained outside the communal life of the Bulgarians, maintaining their group social organisation based on the bonding ties. The reasons for this difference in patterns of the Rudari social positioning among the Bulgarian communities in Spain and Greece should be sought in the different migratory contexts and in the achieved higher or lower degree of social integration of the Rudari within Bulgarian communities.

Bulgarians and Rudari developed similar migration strategies abroad but their patterns of social adaptation have some ethnic specifics. These are mainly the role of bonding ties in social organisation of the group and the ways of employing the social circles' resources. Generally speaking, the boundaries between these groups are preserved. They are not static and are not visible for the local population, to which they look like one and the same group.

The greatest impact on the social cohesion of migrants from Bulgaria in the Greek and Spanish society have the social circles, into which they are included rather than the migration networks, to which they belonged upon arrival. Sometimes the people create a social circle with the migrants they came together with from Bulgaria, but sometimes the social circles are modified because they can include people who arrived in Spain and Greece through other migration channels and can also integrate non-Bulgarian citizens. Moreover, the Bulgarian and the Rudari migrants can become members of the social circles of the Greeks and Spaniards. These social circles maintain pre-existing bonding ties and identities, and produce various bridging social ties, providing their members with social perspectives and opportunities for the emergence of new identity imaginations. Various forms of identity development appeared because some members of the groups began to imagine themselves as part of the local communities and to pretend that they were involved not only in their traditional social circles, but also in social circles of Spaniards and Greeks. The negotiation between identification as Bulgarian citizens and Rudari impacts the way of social organisation of the Rudari and the way they imagine their position in the society. The social circles of migrants from Bulgaria are based on ties with different backgrounds and with different benefits, demonstrating migrants' cultural difference from the local society and their social incorporation within it. 


\section{Notes}

1 През последните години в Гърция пристигат все повече млади емигранти от България [Number of young emigrants from Bulgaria arriving in Greece increased in the recent years], 18 April 2010. Available at http://www.focusnews.net/?id=f14625 (Accessed 24.08.2017).

Всеки трети български емигрант заминава за Испания [Every third emigrant is planning to go to Spain], 27 November, 2010. Available at http://bginfo.es/\%d0\%be\%d0\%b1\%d1\%89\%d0\%b5\%d1\%81\%d1 $\% 82 \%$ d0\%b2\%d0\%be/674-\%d0\%b2\%d1\%81\%d0\%b5\%d0\%ba\%d0\%b8$\%$ d $1 \% 82 \%$ d $1 \% 80 \%$ d $0 \%$ b $5 \%$ d $1 \% 82 \%$ d $0 \%$ b 8 $\%$ d $0 \%$ b $1 \%$ d $1 \% 8$ a $\%$ d $0 \%$ b b $\%$ d $0 \%$ b $3 \%$ b $\%$ b0\%d1\%80\%d1\%81\%d0\%ba\%d0\%b8-\%d0\%b5\%d0\%bc\%d0\%b8\%d0\% b3\%d1\%80\%d0\%b0\%d0\%bd\%d1\%82-\%d0\%b7\%d0\%b0\%d0\%bc\%d0\%b $8 \% \mathrm{~d} 0 \% \mathrm{bd} \% \mathrm{~d} 0 \% \mathrm{~b} 0 \% \mathrm{~d} 0 \% \mathrm{~b} 2 \% \mathrm{~d} 0 \% \mathrm{~b} 0-\% \mathrm{~d} 0 \% \mathrm{~b} 7 \% \mathrm{~d} 0 \% \mathrm{~b} 0-\% \mathrm{~d} 0 \% \mathrm{~b} 8 \% \mathrm{~d} 1 \% 8-$ 1\%d0\%bf\%d0\%b0\%d0\%bd\%d0\%b8\%d1\%8f.html (Accessed 24.08.2017).

${ }^{2}$ Instituto Nacional de Estadística. Renovación del Padrón municipal de habitantes a 1 de mayo de 1996. Datos nacionales, por CC.AA. y provincias. Población por país de nacimiento, nacionalidad y sexo. Bulgaria. Available at http://www.ine.es/jaxi/Datos.htm?path=/t20/e245/p04/a1996/ 11/\&file=00com009.px (Accessed 24.08.2017).

${ }^{3}$ Instituto Nacional de Estadística. Estadística del Padrón continuo a 1 de enero de 2013. Datos a nivel nacional, comunidad autónoma y provincia. Población extranjera por comunidades y provincias, nacionalidad y sexo. Bulgaria. Available at http://www.ine.es/jaxi/Datos.htm?path=/t20/e245/ p04/a2013/10/\&file=0ccaa002.px (Accessed 24.08.2017)

${ }^{4}$ According to data available at the State Agency for Bulgarians Abroad's website (http://www.aba.government.bg/) (Accessed 24.03.2014).

\section{References}

Anderson, Benedict 1991. Imagined Communities: Reflections on the Origin and Spread of Nationalism. London: Verso.

Bourdieu, Pierre 1980. Le capital social: Notes provisoires. Actes de la recherche en sciences sociales, 31, pp. 2-3.

Bourdieu, Pierre 1986. The Forms of Capital. John Richardson (ed.). Handbook of Theory and Research for the Sociology of Education. New York: Greenwood Press, pp. 241-248. 
Brettell, Caroline B. 2005. Voluntary Organizations, Social Capital, and the Social Incorporation of Asian Indian Immigrants in the Dallas-Fort Worth Metroplex. Anthropological Quarterly 78 (4), pp. 853-883.

Čapo Žmegač, Jasna 2008. Parochial Transnationals: Being of Croatian Descent in Germany. Elena Marushiakova (ed.). Dynamics of National Identity and Transnational Identities in the Process of European Integration. Cambridge: Cambridge Scholars Publishing, pp. 323-339.

Coleman, James S. 1988. Social Capital in the Creation of Human Capital. The American Journal of Sociology, 94, pp. 95-120.

Erolova, Yelis 2010. Labour Migrations of the Bulgarian Roma in Poland (A Case Study on Roma from Balchik). Nando Sigona (ed.). Romani mobilities in Europe: Multidisciplinary perspectives. Conference Proceedings. University of Oxford, pp. 52-57.

http://romanimobilities.files.wordpress.com/2010/01/conference-proceedings1.pdf (Accessed 25.08.2017).

Fakiolas, Rossetos \& Maratou-Alipranti, Laura 2000. Foreign Female Immigrants in Greece. Papers, 60, pp. 101-117.

Gabărski, Nikolay 2008. Les expériences migratoires bulgares en Grèce depuis 1989. Balkanologie, 11 (1-2).

http://balkanologie.revues.org/index1142.html (Accessed 25.08.2017).

Gmelch, George 2004. West Indian Migrants and their Rediscovery of Barbados. Oxfeld, Ellen and Long, Lynellyn D. (eds.). Coming Home? Refugees, Migrants, and Those Who Stayed Behind. Philadelphia: University of Pennsilvania Press, pp. 206-225.

Gómez-Mestres, Sílvia \& Molina, Jose Luis 2010. Les nouvelles migrations dans l'Europe: chaînes migratoires, établissement et réseaux sociaux des Bulgares en Espagne et en Catalogne. Balkanologie, 12 (2). http://balkanologie.revues.org/2211 (Accessed 25.08. 2017).

Granovetter, Mark S. 1973. The Strength of Weak Ties. The American Journal of Sociology, 78 (6), pp. 1360-1380.

Kaurinkoski, Kira 2010. Priviliged Co-Ethnic Greek Migrants from the Former Soviet Union in the Greater Athens Area: Reflection on Individual and Collective Integration Strategies into Greek Society. Čapo Žmegač, Jasna (ed.). Co-Ethnic Migrations Compared. Central and Eastern European Contexts. München-Berlin: Verlag Otto Sagner, pp. 119-139.

King, Russel \& Zontini, Elisabeta 2000. The Role of Gender in the South European Immigration model. Papers, 60, pp. 35-52. 
Macías, Almudena 2003. Mujeres inmigrantes extracomunitarias en Navarra. Miguel Laparra Navarro (ed.). Extranjeros en el purgatorio. Intergación social de los inmigrantes en el espacio local. Gobierno de Navarra, Universidad Pública de Navarra: Edicions Bellaterra, S.L., pp. 247-268.

Maeva, Mila 2010. Organizations and Institutions of Bulgarian Imigrations in the UK. Karamihova, Margarita (ed.). Readings in the History and Culture of the Balkans. In Support of the University Teaching. Sofia: Paradigma, pp. 173-195.

Mendoza, Cristóbal 2001. Cultural Dimensions of African Immigrants in Iberian Labour Markets: A Comparative Approach. Russell King (ed.). The Mediterranean Passage. Migration and New Cultural Encounters in Southern Europe. Liverpool: Liverpool University Press, pp. 41-66.

Putnam, Robert 1993. The Prosperous Community. The American Prospect, 13, pp. 35-42.

Putnam, Robert 2000. Bowling Alone: The Collapse and Revival of American Community. New York: Simon and Schuster Paperbacks.

Rangelova, Rossitsa 2006. Gender Dimension of the New Bulgaria's Migration: Comments on Empirical data. Migration Online. http://www.migrationonline.cz (Accessed 25.08.2017).

Slavkova, Magdalena 2007. Циганите евангелисти в България. [Tsiganite evangelisti v Bâlgariya = Evangelical Gypsies in Bulgaria]. Sofia: Paradigma.

Slavkova, Magdalena 2012. From Invisibility to Visibly Successful: Bulgarian Female School Activists in Spain. Ganchev, Alexander et al. (eds.). Migratory Processes in Europe: Evolution of the Migratory Interactions of the EU and Central and Eastern European Countries. Odessa: Center for Migration Studies of Odessa National Academy of Telecommunication named after A.S. Popov (Ukraine), Central European University (Hungary), Center for Migration Research (Russia), pp. 443-462.

Soultanova, Ralitza 2005. Les migrations multiples de la population bulgare. Les Courrier des Balkans.

https://www.courrierdesbalkans.fr/les-migrations-multiples-de-la-population-bulgare

Stanchev, Krassen et al. (ed.). 2005. Bulgarian Migration: Incentives and Constellations. Sofia: Open Society Institute. 


\section{ELM Scholarly Press \\ SATOR 18}

http://dx.doi.org/10.7592/Sator.2017.18

\section{BALKAN AND BALTiCUM}

Current Studies in the Postsocialist Space

Edited by

Ekaterina Anastasova and Mare Kõiva

Tartu 2017 
Editors and compilers: Ekaterina Anastasova, Mare Kõiva Series "Sator" editor: Mare Kõiva

Language editors: Liisa Vesik, Lii Liin

Cover photo: Jaak Kikas, 2017 "Autumn in Tartu"

International committee

Tiiu Jaago (Tartu University); Reet Hiiemäe (Estonian Literary Museum); Mare Kalda (Estonian Literary Museum); Tarmo Kulmar (Tartu University); Nikolay Kuznetsov (Estonian Literary Museum); Aado Lintrop (Estonian Literary Museum); Emily Lyle (School of Scottish Studies in Edinburgh); Mirjam Mencej (Ljubljana University); Jonathan Roper (Tartu University); Marju Kõivupuu (Tallinn University); Ülo Valk (Tartu University); Tatjana Vladõkina (Institute of Udmurtian History, Language and Literarture, Izhkar); Irina Vinokurova (Institute of Karelian History, Language and Literarture in Petroskoi); Ergo-Hart Västrik (Tartu University)

Supported by Estonian Academy of Sciences, Bulgarian Academy of Sciences, the Centre of Excellence in Estonian Studies (CEES, European Regional Development Fund) and is related to research projects IRG 22-5 (Estonian Research Council).

\section{$\boldsymbol{C} E \mathbf{E} \times \begin{aligned} & \text { Centre of excellence } \\ & \text { in Estonian Studies }\end{aligned}$}

Series "Sator. Artikleid usundi- ja kombeloost", 18 http://www.folklore.ee/rl/pubte/ee/sator/sator18/

ISSN 1736-0323 (online)

ISBN 978-9949-586-58-5 (printed)

ISBN 978-9949-586-61-5 (online) ISSN 1406-2011 (printed)

DOI: 10.7592/Sator.2017.18

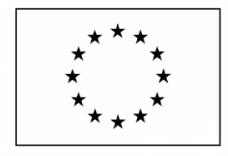

European Union European Regional Development Fund

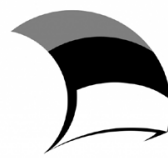

Investing in your future

\section{EUROPEAN UNION}

Regional Development Fund

Investing in your future
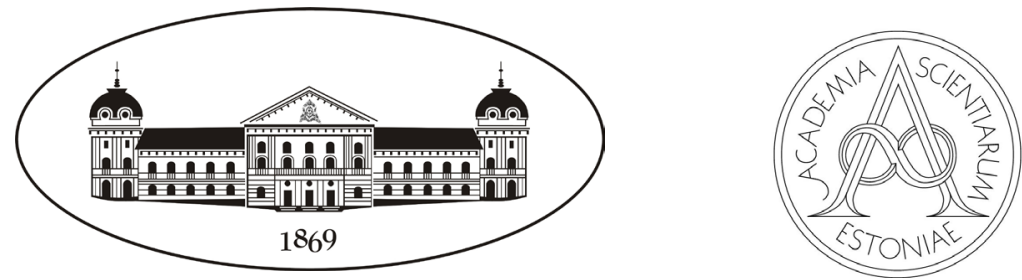


\section{Contents}

Preface

Mare Kõiva, Ekaterina Anastasova

CONSTRUCTING IDENTITY AND SOCIAL TIES

Ethnographic Studies on the Montenegrin

Festive Costume as a National Symbol

Sofiya Zahova

Social Ties of Bulgarians and Rudari in the Mediterranean Countries

Magdalena Slavkova

\section{RECASTING RELIGION AND \\ RELIGIOUS IDENTITY}

Contemporary Development of the Akyazili

Baba Tekke / St. Athanasius in Bulgaria

Yelis Erolova

Turkish Religious Identity in Bulgaria

94

in the Last Twenty-Four Years (1989-2013)

Mila Maeva

The Feast of Cyril and Methodius in Bessarabia and Crimea, Ukraine

Ekaterina Anastasova 
The Saints of Death in the Traditions

of the Balkan People

Rachko Popov

\section{CONSTRUCTING NEW SPIRITUALITY}

New Trends in the Study of Religion in Estonia -

Contemplations in the Grey Zone between

Religion and Science

Tõnno Jonuks

Constructing New Spirituality in Modernity -

the Case of the White Brotherhood in Bulgaria

Svetoslava Toncheva

Constructing Contemporary Periodical and

Occasional Rituals

Mare Kõiva

The Making of a Sacred Place:

221

An Example of Constructing Place Identity in the Contemporary Mentality

Reet Hiiemäe

\section{CHANGING TRADITIONS}

Bridge Over the Rainbow. Animal Burials and

Animal Cemeteries in Post-Socialist Estonia

Marju Kõivupuu

Simple Hide-and-seek at its Core: Play Features and the Game of Geocaching

Mare Kalda 